ISSN: 2414-0325. Open educational e-environment of modern University, special edition (2019)

\author{
Roman Medvediev \\ Master of Specialty 015 "Professional Education (Computer Technology)" \\ Vinnytsia Mykhailo Kotsiubynskyi State Pedagogical University, Vinnytsia, Ukraine \\ romadgan96@gmail.com
}

\author{
Liudmyla Shevchenko \\ Doctor of Pedagogical Sciences, Assistant Professor, Department of Innovative and Information Technologies \\ Vinnytsia Mykhailo Kotsiubynskyi State Pedagogical University, Vinnytsia, Ukraine \\ lysi4801@gmail.com \\ ORCID: 0000-0003-4991-4949

\section{Volodymyr Umanets} \\ $\mathrm{PhD}$ of Pedagogical Sciences, Assistant Professor, Head of Information and Computing Center \\ Vinnytsia Mykhailo Kotsiubynskyi State Pedagogical University, Vinnytsia, Ukraine \\ umkavin@gmail.com \\ ORCID: 0000-0002-7237-4955
}

\title{
ELECTRONIC EDUCATIONAL RESOURCES OF TEACHING OF THE BASIS OF DESKTOP PUBLISHING FOR THE FUTURE TEACHERS OF VOCATIONAL EDUCATION
}

\begin{abstract}
The article describes the experience of designing and using in the process of training future educators professional training of electronic educational resource for the study of computer layout foundations. In the course of our research, we have found out the possibility of using electronic educational resources in the educational process of Higher education institutions to train future teachers of vocational education. In particular, we have developed an electronic educational resource «Basics of Computer Layout», in which, according to, the necessary training materials and author's methodological developments for learning the basics of computer layout in the Adobe InDesign CS5 software environment are structured. The Word Press content management system (CMS), which has open source code and is distributed under the GNU GPL license, has become a popular medium for creating the described ESM. The developed ESM contains a set of copyright educational and methodological materials, materials for monitoring the level of educational achievements, together they allow the future teachers of vocational training to form the theoretical knowledge and practical skills of the basics of computer layout in the Adobe InDesign CS5 software environment. For the purposeful implementation of conceptual research ideas, the author developed a method for using a complex of electronic educational resources for teaching computer graphics to future bachelors of the specialty 015.10 «Professional education (computer technologies)». The method involves the provision of practical knowledge and skills to future bachelors of vocational education in order to form professional competencies in the Special Informatics discipline (module 3 Fundamentals of computer layout in the Adobe In Design CS5 program).
\end{abstract}

Keywords: e-learning resource; computer layout; Adobe InDesign CS5; WordArt; Learning Apps; My Test X; future educators of professional training

Introduction. The current stage of the development of higher education of Ukraine is characterized by a special intensity and scale of transformations, caused in particular by the European integration and globalization processes, which require reloading of the system of higher education in the direction of informatization and optimization of the educational process. In this context, the problem of finding innovative methods, forms and means of learning is based on information and communication technologies (ICTs), which are going to create a new generation of teachers, to provide an increase of the quality of training of future specialists in the field of education, in particular, teachers of vocational training.

One of the ways of solving the problem of finding innovative methods, forms and means of training is the development and introduction of electronic educational resources (EER) in the educational process of higher education institutions (HEI). 
Analysis of recent research and publications. Some experience in creating electronic educational resources is reflected in the works of V. Bykov, V. Gur, L. Zainutdinova, L. Kartashova, N. Olefirenko, A. Osina and others. The basis of the technology of designing electronic educational resources offered by these scientists is laid psychological and pedagogical requirements, models of content and mastering of educational material, modern concepts of information and education environment and the methodology of designing EER. In addition, the works of these scholars indicate that an important aspect of the EER's design process is the compliance of its structure with the requirements for the structure of electronic educational resources, as set forth in the "Regulations on Electronic Educational Resources" ("Provisions on electronic educational resources", 2019).

Research results. The development of information technologies (IT) and learning tools (R \& D) on their basis began to develop in Ukraine in the 1970's, but today, in spite of all the efforts of both educators and scientists, IT is used insufficiently and inefficiently, the development of information and communication technologies has determined the emergence of a new form of education - e-learning, teaching using ICT.

The basis of electronic education is the electronic educational resources (EER), the concept EER in Ukraine became commonly used at the beginning of the XXI century. According to the order of the Ministry of Education and Science, Youth and Sports of Ukraine No. 1060 of 10/01/2012 "About Approval of the Regulation on Electronic Educational Resources" ("Provisions on electronic educational resources", 2019) its basic definition was fixed: “... educational, scientific, informational, reference materials and tools developed in electronic form and presented on media of any type or placed on computer networks reproduced by means of electronic digital means and necessary for the effective organization of the educational process, in the part concerning its filling educational materials ..." .

The main types of EER, as O. Spirin mentions (Spirin, 2010, p. 81), include the following: an electronic document; e-edition; electronic analogue of the printed publication; electronic didactic demonstration materials; depository of electronic resources; computer test; electronic dictionary; electronic directory, etc. According to the functional feature of EER can be classified as: educational, methodological, educational, auxiliary, controlling.

Electronic educational resources from the technical point of view - a set of programs and data, from the point of view of the consumer - is the content, that is, a set of content elements representing objects, processes, abstractions, which are the subject of study. At the same time, effective EERs have a high degree of interactivity and multimedia saturation, and also have the ability to network distribution (Rashevskaya, 2011).

As N. Morseau and O. Glazunov mentioned (Morse, Hlazunova, 2008, p. 42-43), the EER must meet the following requirements: compliance with the curriculum for which the EER has been developed; availability of appropriate methodological recommendations of the use of EER in the professional activity of the teacher / teacher; observance of the current sanitary, ergonomic, programmatic and technical requirements and norms to the EER; conformity with international technical standards (SCORM, Experience API, etc.); compliance with Ukrainian legislation. EER does not require duplication in paper form.

As O. Matviychuk-Judin wrote (Matviychuk-Yudina, 2011, p. 256), which developing the EER, arbitrary instrumental software, hardware and hardware may be used subject to the requirements for the creation and use of copyright and related rights objects regulated by the Law of Ukraine "On Copyright and Related Rights" and other legislative acts Of Ukraine.

According to the EER in accordance with the above-mentioned requirements, with the use of the software tools of the content management system (CMS) Word Press, which has open source and distributed under the GNU GPL license, an electronic educational resource for learning of desktop publishing was developed (Fig.1). 
ISSN: 2414-0325. Open educational e-environment of modern University, special edition (2019)

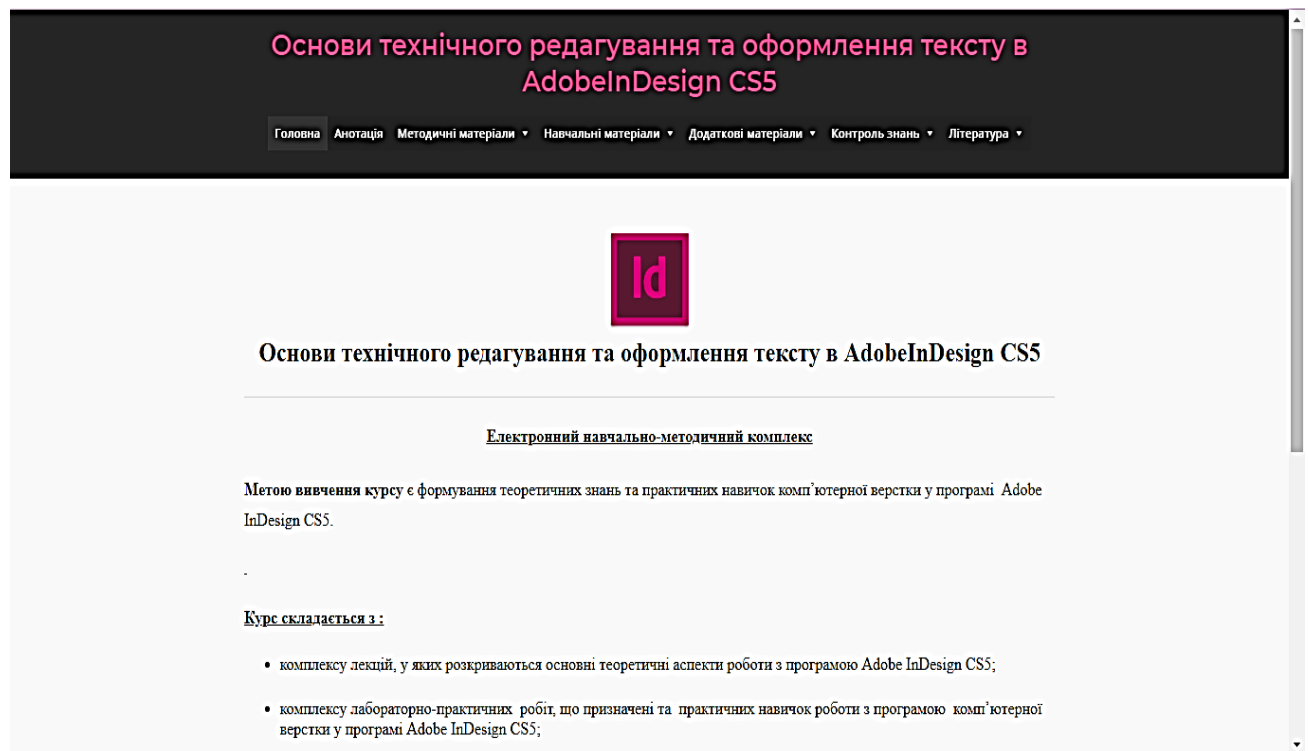

Fig. 1. Home page of the electronic educational resource "Basics of desktop publishing"

The developed EER contains a set of author's educational and methodological materials, materials for monitoring the level of educational achievements, which in aggregate allow the future teachers of professional training to develop theoretical knowledge and practical skills of the basics of computer layout in the software environment Adobe InDesign CS5.

In order to visualize the educational material, to ensure the interactivity of the educational process, to increase the interest of students in the study of the basics of computer layout, to deepen their knowledge and to realize the educational tasks of the discipline, we used the following services:

1. WordArt is a web service that allows you to create a cloud of words from text entered by the user or from a web page with the address. The cloud may have a different shape and color solution. Each word cloud is a hyperlink to search on Google. In our EOR, using the cloud of tags, a glossary of the main terms for each topic is implemented (Fig. 2).
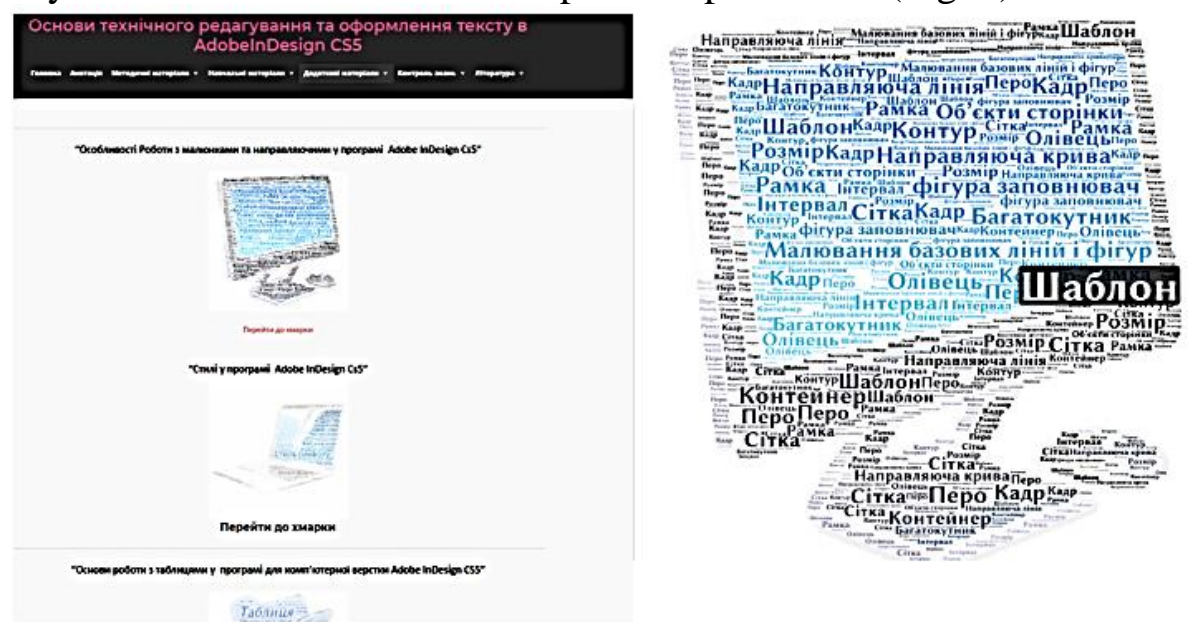

Fig. 2. The cloud of tags, a glossary of the main terms for each topic is implemented

2. Mind Meister - a service for creating mental maps (knowledge maps).

Mental maps are one of the ways to process information graphically and visually, the type of recording ideas and thoughts. The essence of building a mental map is that with the help of 
clear symbols, images, objects, associations, which the person thinks, clearly depict a coherent picture of knowledge about the subject of study, consideration. In the developed EER, mental maps are positioned as reference abstracts of key concepts of each topic (Fig. 3).

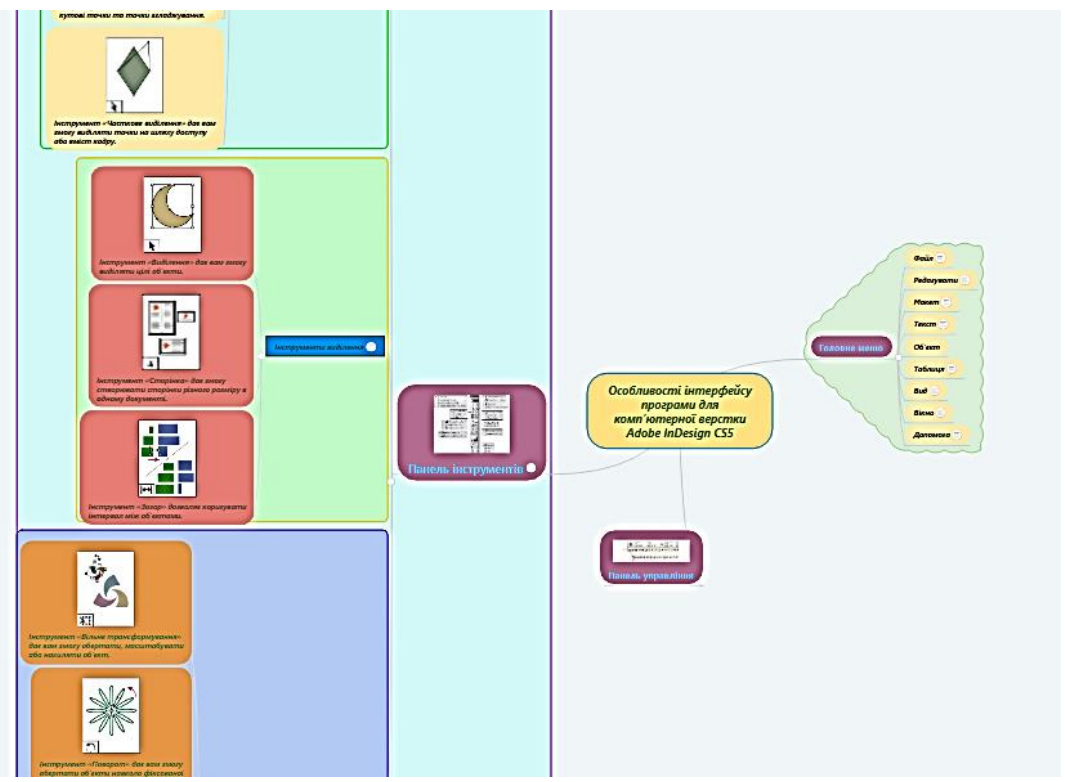

Fig. 3. A set of mental maps as a didactic material for lectures on the basics of computer layout

It is worth noting the positive aspects of the use of YouTube video hosting in the educational process, which allows the placement of educational videos with the ability to create a teacher of their own YouTube channel. In the structure of didactic materials developed by us EOR, an important place is occupied by a set of specially selected and structured video tutorials on the basics of work in the computer layout environment (Fig. 4).

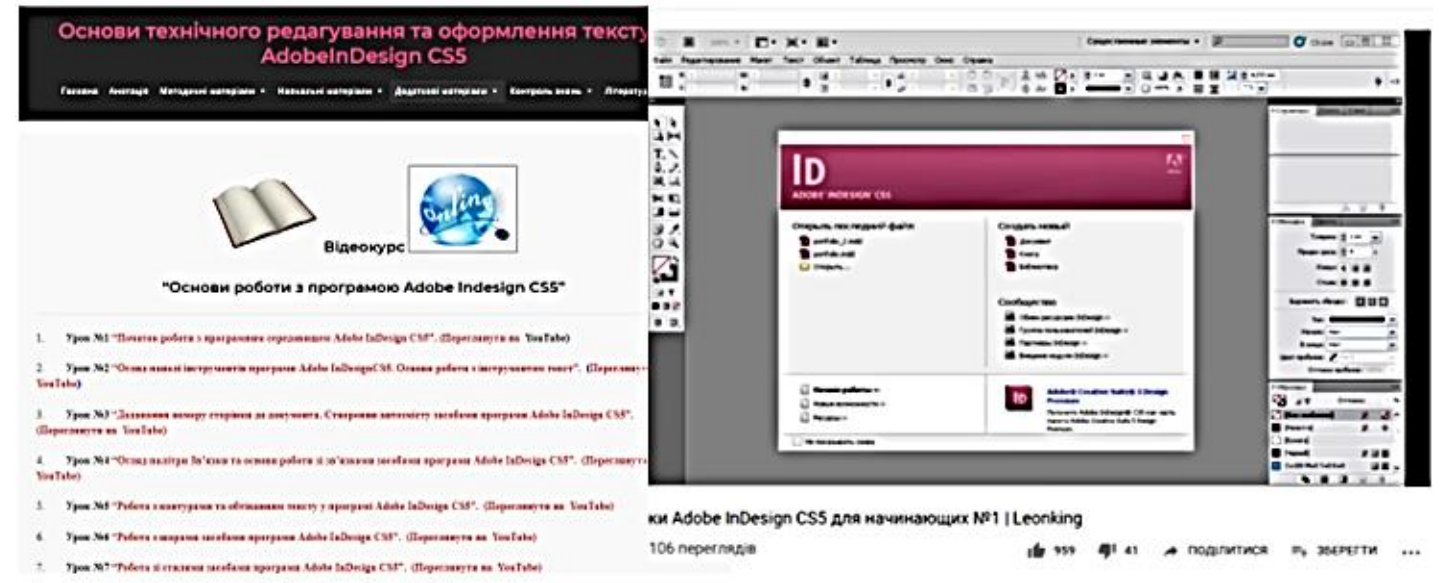

Fig. 4. A set of video tutorials for presenting educational material

An important stage in the educational process is knowledge control. In order to test the acquisition of knowledge acquired by students, it is expedient to use the services for creating tests. Teachers who are users of a Google Account in this situation are comfortable to use the Google Forms service ( Fig. 5), which allows you to create test questionnaires that can contain different types of questions (with the choice of one correct answer, with multiple the choice of the right answers, questions on the comparison, the question with the introduction of a short answer, the establishment of logical or chronological sequence, etc.). 
ISSN: 2414-0325. Open educational e-environment of modern University, special edition (2019)

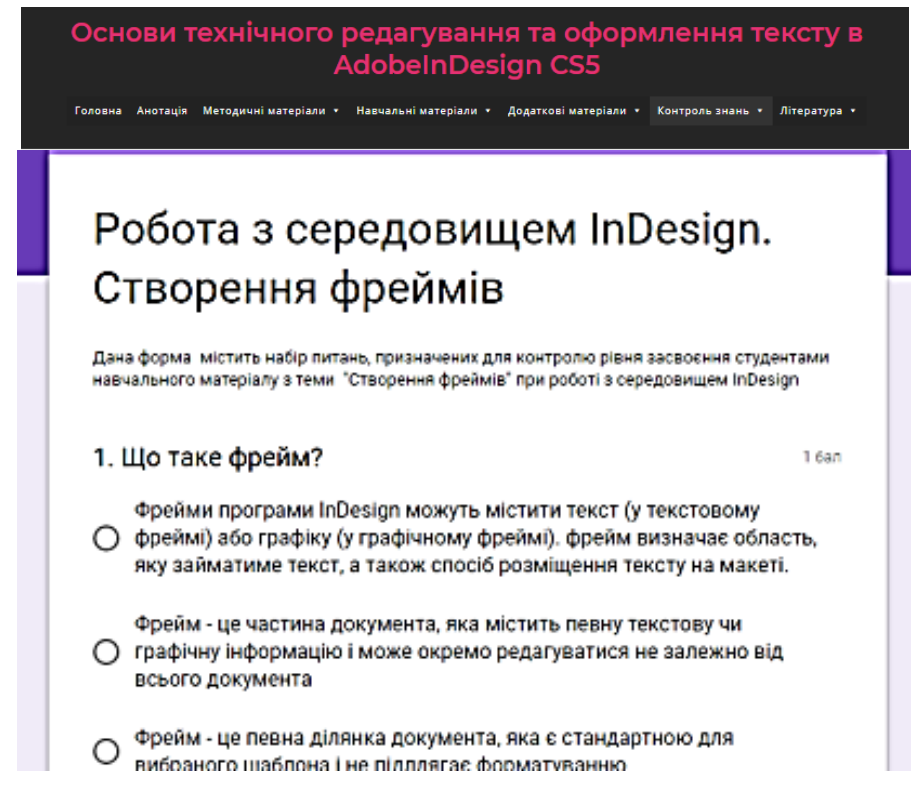

Fig. 5. A set of test tests to consolidate the theoretical material developed by the services of Google Form

Among the local software products for creating control tests often use the service My Test X (Fig. 6).
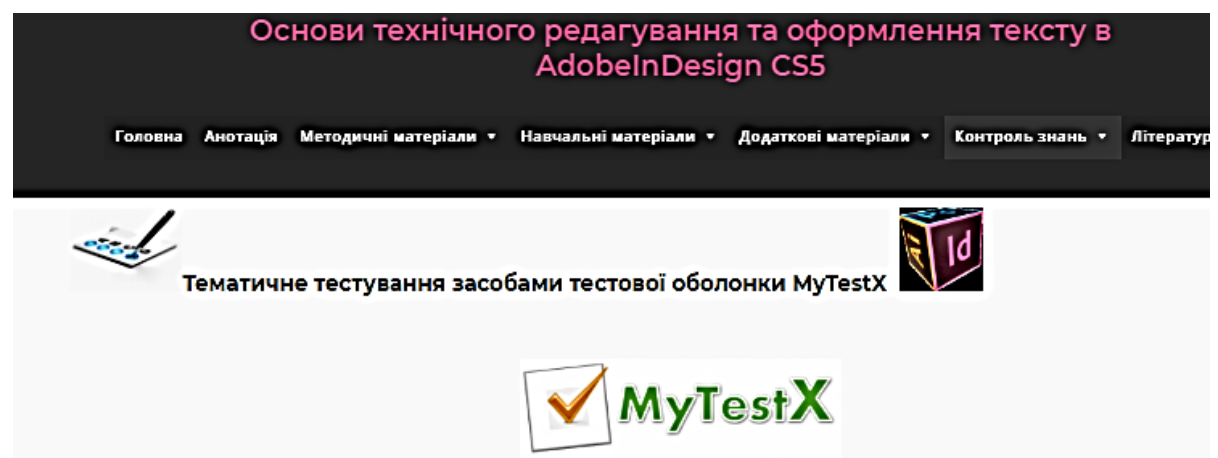

Fig. 6. Thematic testing with means of the test shell MyTestX

In the EER we have developed, to create control tests, in addition to the described services also used the features of the program MS PowerPoint with a specially-written macros "Testing " With this program we created a thematic blitz test for each of the topics of the lecture (Fig. 7). 


\section{Бліщ-Тест}

ЛПР1 «Робота з середовищем InDesign.

Робота 3 головним меню, вікном та

панелями інструментів.»

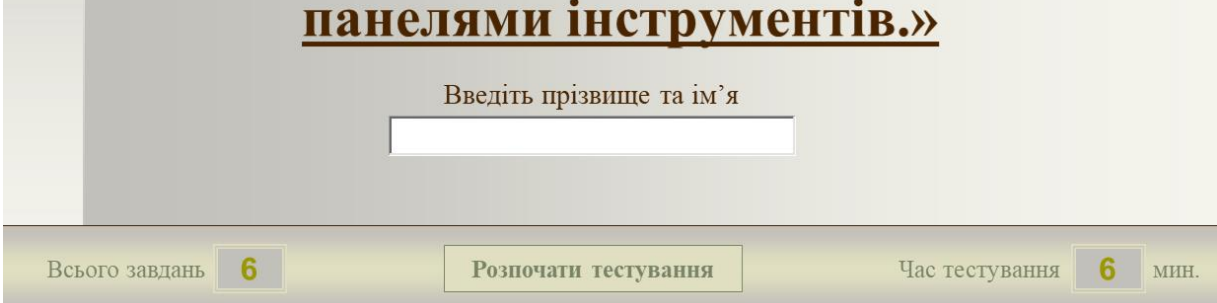

Fig. 7. A set of test blitz tests for fixing the theoretical material developed by MS Power Point

Advantage of such testing is to run it without installing special software and connecting to the Internet.

Also, to test the acquired knowledge, we used the didactic materials created with the Learning Apps service (Fig. 8), Web 2.0 service to support educational processes in various types of educational institutions. This is a constructor for the development of interactive tasks for various subject disciplines for use in lessons and in extracurricular work (Andreev, 2002, p. $100)$.
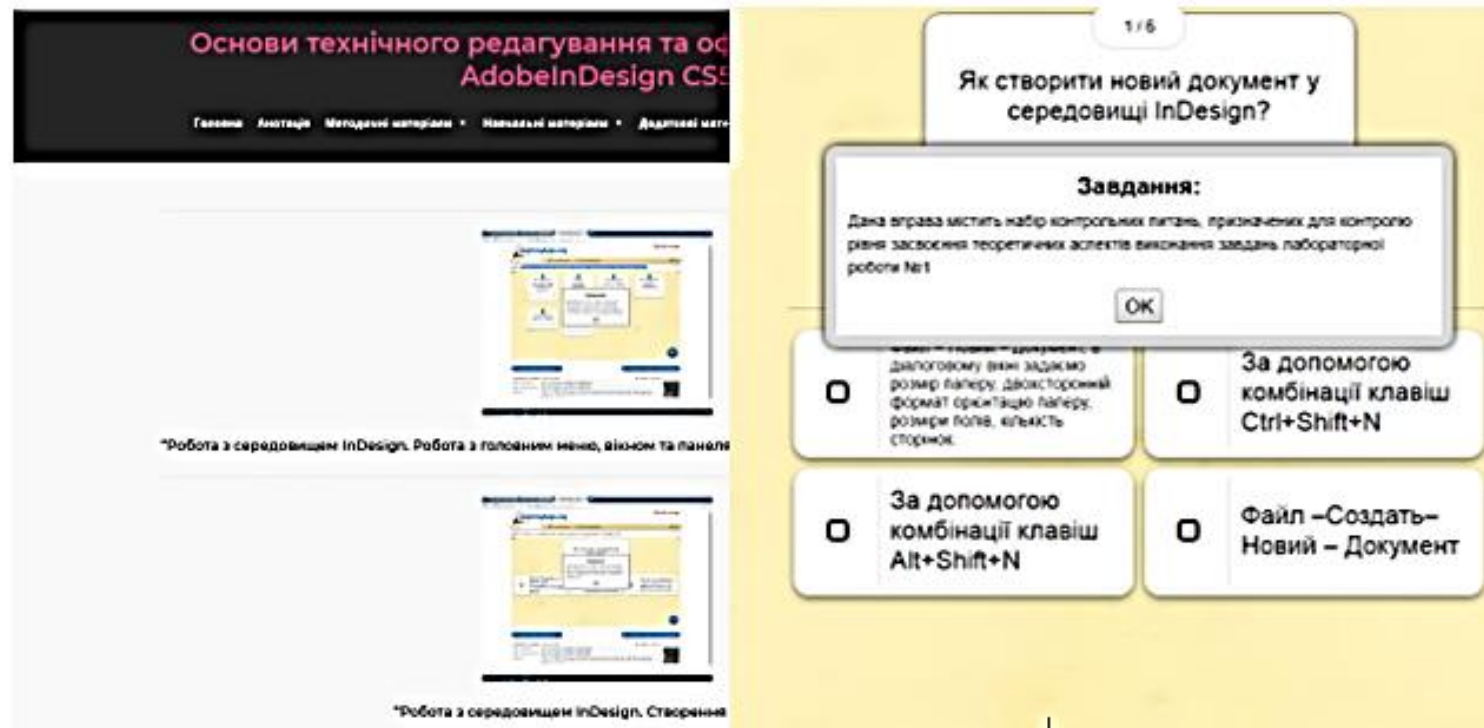

Fig. 8. A set of interactive exercises of various types, developed by the Learning Services online services

The service contains a gallery of public interactive tasks, which is updated daily with new materials created by teachers from different countries.

The use of the software and hardware tools described above has made it possible to maximize the structuring and visualization of teaching materials and make the educational process interactive. We believe that this kind of presentation of educational material allows graduates of HEI not to drown in the flow of theoretical material, and it is easy to find answers 
to questions that arise during the study process of the basics of work in the Adobe InDesign CS5 environment.

To confirm the formulated hypothesis we conducted an experiment in 2 groups of 3rd year students of higher education level "Bachelor" specialty 015.10 "Vocational Education (Computer Technologies)".

As a criterion for analyzing the level of educational achievement of both groups, we take the current semester grades and, using mathematical statistics methods, determine how important the difference in grades is, and, therefore, whether these groups can be equated as having the same level of knowledge in the subject.

For the experiment in group 1, the training was conducted according to the experimental method, and in 2 - according to the traditional one. In the control group, the method of conducting lessons did not change, and in the experimental group the developed EER was used.

Determination of Student's Criterion

1. The calculation of the arithmetic mean of the formula:

$\mathrm{M} 1=\sum \mathrm{X} 1 / \mathrm{N} 1=90 / 11 ; \mathrm{M} 1=8.18 ; \mathrm{M} 2=\sum \mathrm{X} 2 / \mathrm{N} 2=59 / 8 ; \mathrm{M} 2=7.38$;

where $\sum X 1,2$ is the arithmetic mean; N1,2 - number of students; $\sum X 1=90 ; \sum X 2=59$; $\mathrm{N} 1=11 ; \mathrm{N} 2=8$.

2. The calculation of indicators of variation:

$\mathrm{SS} 1=\sum \mathrm{X} 21-\left(\sum \mathrm{X} 1 / \mathrm{N} 1\right) 2=902-(90 / 11) 2 ; \mathrm{SS} 1=8033 ; \mathrm{SS} 2=\sum \mathrm{X} 22-\left(\sum \mathrm{X} 2 / \mathrm{N} 2\right) 2$ $=592-(59 / 8) 2 ; \mathrm{SS} 2=3426$.

3. Find the degree of variation or variance: S21 = SS21 / N1 - 1; S21 = 803.3;

$\mathrm{S} 22=\mathrm{SS} 22$ / N2 - 1; S22 = 489.4; S1 $\sqrt{\mathrm{SSS}} 1 / \mathrm{N} 1$ - 1;

$\mathrm{S} 1=28.34$

$\mathrm{S} 2=\sqrt{\mathrm{SS}} 2 / \mathrm{N} 2-1 ; \mathrm{S} 2=22.12$.

4. The calculation of the statistical error of the arithmetic mean error:

$\mathrm{Sm} 1=\sqrt{\mathrm{SS}} 1 / \mathrm{N} 1(\mathrm{~N} 1-1) ; \mathrm{Sm}=8.54 ; \mathrm{CM} 2=\sqrt{\mathrm{SS}} 2 / \mathrm{N} 2(\mathrm{~N} 2-1) ; \mathrm{Cm} 2=7.82$.

5. Determination of permissible error:

$\Delta 1=\mathrm{M} 1 \pm 1.96 * \mathrm{Sm} 1 ; \Delta 1=8.12 \pm 1.96 * 8.54 ; \Delta 2=\mathrm{M} 2 \pm 1.96 * \mathrm{Sm} 2 ; \Delta 2=7.375 \pm$ $1.96 * 7.82$.

6. Definition of standard error of difference of arithmetic mean: CM1-M2 $=\sqrt{ } \mathrm{S} 1+\mathrm{S} 2 /$ $\mathrm{N} 1+\mathrm{N} 2-2 *(1 / \mathrm{N} 1+1 / \mathrm{N} 2) ; \mathrm{Cm} 1-\mathrm{m} 2=0,8$.

7. Definition of Student's t test: $\mathrm{t}=\mathrm{M} 1$ - M2 / Sm1-m2; $\mathrm{t}=1,006$.

During the organization of experimental work, experimental classes did not violate the normal mode of work and the course of the educational process and were held under the usual rules, not separated from the whole system.

Basic requirements for subjects of the educational process of higher education institutions were analyzed. It has been determined that in order for the use of EER to be effective, graduates also have to meet certain requirements, namely to have self-education skills; to be disciplined and interested in own development; to be able to use ICT tools in the process of self-education, in particular to use the Internet and services based on cloud-based technologies; have the skills of communication using modern services and hardware and software. It was investigated that the teacher for work with electronic educational resources should not only meet the traditional requirements of the teacher (organizing, didactic, perceptual, compilative, suggestive, scientific, cognitive, subject), but also should have a high level of IC-competence, and be able to use modern instrumental software, technical and hardware tools and services in pedagogical activity.

The generalized results of the conducted research confirms the efficiency of using the electronic educational resource of the training of the basics of computer modeling of future teachers of vocational education; Experimental work has proven that electronic educational 
resources are new alternatives to traditional methods of organizing the educational process, methods and tools that provide the opportunity for individual learning, collective teaching and conducting online classes.

The obtained results testify to the need for further in-depth study of the specifics of the use of EER in the educational process of institutions of higher education, in particular: coordination of the work of teachers on the development of integrated integrated methods of the use of electronic educational resources, the development of didactic provision taking into account the perspective directions of the development of innovative technologies.

Research results. Our research and their experimental verification confirm the effectiveness and innovation of the use of EOP in the process of training future educators in vocational training.

Thus, based on our research, we can state that electronic educational resources are new alternatives to traditional methods of organizing an educational process, methods and tools that provide the opportunity for individual learning, collective teaching and conducting online classes.

\title{
REFERENCES
}

Provisions on electronic educational resources: Zat. by order of the Ministry of Education and Science, Youth and Sports of Ukraine from 1 October. 2012 № 1060. in ed. as of February 132019 Verkhovna Rada of Ukraine (2019). May 25, 2019. http://zakon4.rada.gov.ua/laws/show/z1695-12 (in Ukrainian).

Spirin, O. (2010). Criteria of external evaluation of the quality of information and communication technologies of training. Scientific journal of NP Drahomanov NPP. Series 2. Computer-Oriented Learning Systems: Sb. sciences Kyiv, 9 (16), 80-85. (in Ukrainian).

Rashevskaya, N. (2011). Mobile Information and Communication Technologies for Higher Mathematics Students in Higher Technical Education Institutions: (Diss. Candidate ped Sciences): 13.00.10. Kyiv, 244 p. (in Ukrainian).

Morse, N. \& Hlazunova, O. (2008). Evaluation of the quality of electronic learning resources. Scientific notes of the Ternopil State Pedagogical University named after. V. Hnatyuk. Series: Pedagogy, 7, 37-52. (in Ukrainian).

Matviychuk-Yudina, O. (2011). Modern pedagogical requirements and norms of introduction of informatization of educational process in high school. Scientific notes of the Ternopil National Pedagogical University named after. V. Hnatyuk. Series: Pedagogy. Ternopil, 254-25 (in Ukrainian).

Andreev, A. (2002). Pedagogy of higher education. New course - Moscow: Moscow International Institute of Econometrics, Informatics, Finance and Law, 264 p. (in Russian).

\section{ЕЛЕКТРОННИЙ ОСВІТНІЙ РЕСУРС НАВЧАННЯ ОСНОВ КОМП'ЮТЕРНОӤ ВЕРСТКИ МАЙБУТНІХ ПЕДАГОГІВ ПРОФЕСІЙНОЇ ОСВІТИ}

\author{
Медведсв Роман Петрович \\ Здобувач СВО «магістр» спеціальності 015 «Професійна освіта (комп’ютерні технологіï)» \\ Вінницький державний педагогічний університет імені Михайла Коцюбинського, Вінниця, Україна \\ romadgan96@gmail.com
}

\footnotetext{
Шевченко Людмила Станіславівна

Доктор педагогічних наук, доцент, доцент кафедри інноваційних та інформаційних технологій в освіті Вінницький державний педагогічний університет імені Михайла Коцюбинського, Вінниця, Україна lysi4801@gmail.com ORCID: 0000-0003-4991-4949
} 
ISSN: 2414-0325. Open educational e-environment of modern University, special edition (2019)

\section{Уманець Володимир Олександрович}

Кандидат педагогічних наук, доцент кафедри інноваційних

та інформаційних технологій в освіті, начальник інформаційно-обчислювального відділу Вінницький державний педагогічний університет імені Михайла Коцюбинського, Вінниця, Україна umkavin@gmail.com

ORCID: 0000-0002-7237-4955

Анотація. У статті описано результати теоретико-експериментального дослідження проблеми розробки і використання комплексу електронних освітніх ресурсів навчання комп'ютерної верстки у процесі професійної підготовки майбутніх бакалаврів спеціальності 015.10 «Професійна освіта (комп’ютерні технології)». У процесі нашого дослідження, нами було з'ясовано можливості використання електронних освітніх ресурсів в освітньому процесі 3ВО для підготовки майбутніх педагогів професійної освіти. Зокрема нами розроблено електронний освітній ресурс «Основи комп’ютерної верстки» в якому, відповідно до, структуровано необхідні навчальні матеріали та авторські методичні розробки для вивчення основ комп'ютерної верстки в програмному середовищі Adobe InDesign CS5. Середовищем для створення описаного ЕОР стала популярна система керування вмістом сайту (CMS) Word Press, яка має відкритий вихідний код та поширюється під ліцензією GNU GPL. Розроблений EOP містить комплекс авторських навчальних та методичних матеріалів, матеріалів для контролю рівня навчальних досягнень, що в сукупності дозволяють формувати у майбутніх педагогів професійного навчання теоретичні знання та практичні навички основ комп'ютерної верстки у програмному середовищі Adobe InDesign CS5. Для цілеспрямованої реалізації концептуальних ідей дослідження розроблено авторську методику використання комплексу електронних освітніх ресурсів навчання комп'ютерної графіки майбутніх бакалаврів спеціальності 015.10 «Професійна освіта (комп'ютерні технології)». Методика передбачає надання практичних знань, умінь і навичок майбутнім бакалаврам професійної освіти 3 метою формування професійних компетентностей 3 навчальної дисципліни «Спеціальна інформатика» (модуль 3 «Основи комп’ютерної верстки в програмі Adobe In Design CS5»).

Ключові слова: електронний освітній ресурс; комп'ютерна верстка; Adobe InDesign CS5; WordArt; Learning Apps; My Test X; майбутні педагоги професійного навчання 